\title{
Mobility and Attenuation Dynamics of Potentially Toxic Chemical Species at an Abandoned Copper Mine Tailings Dump
}

\author{
Wilson Mugera Gitari ${ }^{1,2, *} \mathbb{C}$, Rendani Thobakgale ${ }^{1,2}$ and Segun Ajayi Akinyemi ${ }^{2,3}$ \\ 1 Environmental Remediation and Water Pollution Chemistry Group, School of Environmental Sciences, \\ University of Venda, Private Bag X5050, Thohoyandou, Limpopo 0950, South Africa; \\ rthobakgale@gmail.com \\ 2 Department of Ecology and Resources Management, University of Venda, Private Bag X5050, Thohoyandou, \\ Limpopo 0950, South Africa; segun.akinyemi@eksu.edu.ng \\ 3 Department of Geology and Applied Geophysics, Ekiti State University, Ado Ekiti P.M.B. 5363, Nigeria \\ * Correspondence: mugera.gitari@univen.ac.za; Tel.: +27-159-628-572
}

Received: 18 December 2017; Accepted: 5 February 2018; Published: 12 February 2018

\begin{abstract}
Large volumes of disposed mine tailings abound in several regions of South Africa, as a consequence of unregulated, unsustainable long years of mining activities. Tailings dumps occupy a large volume of valuable land, and present a potential risk for aquatic systems, through leaching of potentially toxic chemical species. This paper reports on the evaluation of the geochemical processes controlling the mobility of potentially toxic chemical species within the tailings profile, and their potential risk with regard to surface and groundwater systems. Combination of $\mathrm{X}$-ray fluorescence (XRF), X-ray diffraction (XRD), and scanning electron microscopy-energy dispersive spectroscopy (SEM-EDS) techniques, show that the tailing profiles are uniform, weakly altered, and vary slightly with depth in both physical and geochemical properties, as well as mineralogical composition. Mineralogical analysis showed the following order of abundance: quartz $>$ epidote $>$ chlorite $>$ muscovite $>$ calcite $>$ hematite within the tailings profiles. The neutralization of the dominant alumino-silicate minerals and the absence of sulfidic minerals, have produced medium alkaline $\mathrm{pH}$ conditions (7.97-8.37) at all depths and low concentrations of dissolved $\mathrm{Cu}(20.21-47.9 \mu \mathrm{g} / \mathrm{L})$, $\mathrm{Zn}(0.88-1.80 \mu \mathrm{g} / \mathrm{L}), \mathrm{Pb}(0.27-0.34 \mu \mathrm{g} / \mathrm{L})$, and $\mathrm{SO}_{4}{ }^{2-}(15.71-55.94 \mathrm{mg} / \mathrm{L})$ in the tailings profile leachates. The relative percentage leach for the potentially toxic chemical species was low in the aqueous phase ( $\mathrm{Ni} 0.081 \%, \mathrm{Cu} 0.006 \%$, and $\mathrm{Zn} 0.05 \%$ ). This indicates that the transport load of potentially toxic chemical species from tailings to the aqueous phase is very low. The precipitation of secondary hematite has an important known ability to trap and attenuate the mobility of potentially toxic chemical species $(\mathrm{Cu}, \mathrm{Zn}$, and $\mathrm{Pb})$ by adsorption on the surface area. Geochemical modelling MINTEQA2 showed that the tailings leachates were below saturation regarding oxyhydroxide minerals, but oversaturated with $\mathrm{Cu}$ bearing mineral (i.e., cuprite). Most of the potentially toxic chemical species occur as free ions in the tailings leachates. The precipitation of secondary hematite and cuprite, and geochemical condition such as $\mathrm{pH}$ of the tailings were the main solubility and mobility controls for the potentially toxic chemical species, and their potential transfer from tailings to the aqueous phase.
\end{abstract}

Keywords: copper tailings dump; leaching; $\mathrm{pH}$; mobility; chemical species; attenuation mechanisms; aquatic systems 


\section{Introduction}

South Africa has a long history of mining activities dating back for a century, and this has been pivotal for the economy of the country leading to the development of infrastructures and the establishment of other manufacturing industries [1]. However, a consequence of unsustainable and unregulated long years of mining activities, resulted in a large volume of tailings dumps abounding in several regions including poor communities of the country, and this poses a risk to the surrounding environment adjacent to the disposed tailings dumps. Moreover, tailings dump disposal has been reported to occupy large hectares of valuable land that can be used for development projects ensuring employment generation [2]. In South Africa, the majority of the tailings are gold tailings dumps within the Witwatersrand basin in Johannesburg occupying an estimated surface area of $200 \mathrm{~km}^{2}$ [3]. Other tailings dumps include the abandoned copper tailings dump in Musina occupying an estimated surface area of $4.99 \mathrm{~km}^{2}$, and the abandoned cassiterite tailings dump located at the eastern limb of the Bushveld complex in Mokopane covering an estimated surface area of $3.9 \mathrm{~km}^{2}$ [4,5]. Tailings dump characteristics vary accordingly depending on the type of the ore mined, mining equipment used, chemicals implemented during mineral processing, mineralogy and geochemistry, and particle size of the tailings [6]. However, tailings dumps generally contain un-wanted and un-economic minerals bound with the mined ore, potentially toxic chemical species $(\mathrm{Cu}, \mathrm{Pb}, \mathrm{Zn}, \mathrm{Co}$, and $\mathrm{Ni})$ bound to minerals present within the tailings dump, and inorganic chemicals such as sulfuric acid used to enhance ore separation during mineral processing [7]. Nevertheless, the disposal of an enormous volume of tailings dumps poses a serious risk to the surrounding environment through air pollution due to air-dried out tailings, erosion of the tailings with the potential of valuable land degradation, and leaching of soluble inorganic potentially toxic chemical species $(\mathrm{Cu}, \mathrm{Ni}, \mathrm{Pb}, \mathrm{Zn}, \mathrm{Cd}$, and $\mathrm{Cr})$ occurring in a variety of minerals present in the tailings dump [8]. The leaching or release of soluble inorganic potentially toxic chemical species from tailings dumps into the adjacent surface and groundwater systems has been reported to be a major environmental concern induced by tailings dumps [7,9]. When sulfide minerals (mainly pyrite) present within the tailings are in contact with atmospheric oxygen and infiltrating rain water, the tailings become susceptible to oxidative weathering, consequently resulting in the formation of acidic mine drainages with low $\mathrm{pH}$ conditions laden with high concentration of sulfates $\left(\mathrm{SO}_{4}{ }^{2-}\right)$, and potentially toxic chemical species [10-12]. Under this geochemical condition, many of the potentially toxic chemical species become highly soluble and mobile, and consequently, this may contaminate the receiving surface and groundwater systems, thereby causing changes to local groundwater dynamics in terms of both quantity and quality of water and its flow direction, and may further cause loss for aquatic habitat and the establishment of alien invasive species [13]. Groundwater in the mining district of Johannesburg in South Africa is heavily contaminated by potentially toxic chemical species, and becomes acidic because of oxidative weathering of pyrite present within the mine tailings dumps [14]. The duration of these environmental impacts can be long-term.

However, this is mainly attributed to the absence of minerals in the tailings that can neutralize the acidity generated during sulfide oxidation [9]. According to Bortnikova et al. [15], the main minerals within the tailings, decreasing the acidity, are carbonates such as calcite, dolomite, siderite, and alumino-silicates such as chlorite, epidote, and plagioclase. According to Romero et al. [7], neutralization of the acidity in the tailings occurs through the dissolution of these carbonate and alumino-silicate minerals, which consume hydrogen ions and generate neutral to medium alkaline $\mathrm{pH}$ conditions within the tailings systems. Under medium alkaline $\mathrm{pH}$ condition, the solubility and mobility of many potentially toxic chemical species becomes low, consequently, dissolved concentrations of potentially toxic chemical species in tailings leachates and pore waters becomes relatively low, mitigating the environmental severity of potentially toxic chemical species $[7,9,16]$. Sulfide oxidation and neutralization processes have a great influence on the solubility and mobility of potentially toxic chemical species and their retention in primary and secondary mineral phases within the tailings [9]. Thus, contamination of the adjacent surface and groundwater ecosystems 
is dependent on the solubility and mobility of the potentially toxic chemical species, which is a function of $\mathrm{pH}$ and mineralogy of the tailings [7]. In order to assess the current environmental state and potential contamination on aquatic systems induced by tailings dump disposal, it is necessary to understand the geochemical behavior of the chemical constituents and the natural geochemical conditions of the disposed tailings. Nevertheless, in South Africa, much of the previous work done on disposed tailings focused on physicochemical and mineralogical characterization of copper and gold tailings with the view to assessing the beneficial application in the construction industry [17]. Matshusa and Makgae [18] characterized the abandoned mine tailings in Limpopo, and the rehabilitation challenges. Singo [19] studied the assessment of heavy metal pollution on soils adjacent to the old copper mine tailings in Musina. Nonetheless, the challenge is to understand the leaching behavior of the potentially toxic chemical species with tailings depth, when the disposed copper tailings are in contact with atmospheric oxygen and infiltrating rain water over the long-term. This is crucial when assessing the current state of the disposed copper tailings and potential risk on the adjacent aquatic systems. The present paper reports on evaluation of the geochemical processes controlling the solubility and mobility of potentially toxic chemical species within the established copper tailings profiles. The potential transfer and risk of potentially toxic chemical species from tailings to the adjacent surface and groundwater systems is elucidated.

\section{Materials and Methods}

\subsection{Study Area and Sampling Techniques}

The study area is located at Musina $\left(22^{\circ} 20^{\prime} 17^{\prime \prime} \mathrm{S}\right.$ and $\left.30^{\circ} 02^{\prime} 30^{\prime \prime} \mathrm{E}\right)$, a small town at the northern end of Limpopo Province, South Africa. The town of Musina has a long history of mining activities and is a home to several successful mining companies, some of which are not working anymore. Nevertheless, some of the exploited mineral resources in the region include iron ore, coal, copper, graphite, magnetite, asbestos, diamonds, and semi-precious stones [17]. However, copper mining in Musina dates from 1906 when the Musina Development Mining Company started to mine copper ore, and since then over 40 million tons of ore have been mined, recovering about 700,000 tons of copper from chalcopyrite, bornite, and chalcocite as the primary minerals [20]. The mined ore was processed in an erected concentrator, and copper concentrates were recovered by flotation thickening, and the waste was rejected from the concentrator as tailings dump (Figure 1). Nonetheless, copper mining activities in Musina stopped in 1992, whereby poor ventilation and water seepage into the mine have also been speculated in forcing the mine to stop operation [21]. Thus, the abandoned copper tailings dump disposal in Musina has been exposed to weathering for a period of 25 years [18]. Moreover, geologically, the Musina area is characterized by medium-high grade metamorphic rocks of which the Sand River Gneiss is the oldest (3.7 Ma) and form the basement to a sequence of rock covers of the Beit bridge complex, which according to their dominant lithology are subdivided into the Mount Dowe, Malala Drift, and Gumbu Group [22].

To meet the aim of the study, three tailings profiles were established, drilled to depths of $5 \mathrm{~m}$ (tailings profile $\mathrm{A}$ and $\mathrm{B}$ ) and $3 \mathrm{~m}$ (tailings profile $\mathrm{C}$ ) respectively. Tailings profiles $\mathrm{A}$ and $\mathrm{B}$ are located at the southern-central sector, meanwhile tailings profile $C$ is located at the north-eastern sector of the abandoned copper tailings dump (Figure 1). However, due to the uniform mineralogical and geochemical characteristics of the tailings, only tailings profile B and C were considered for this study. A systematic sampling grid technique was commissioned by using a square grid and collecting samples from the nodes (interactions of the gridline). At each node, tailings samples were collected at regular depth intervals with the use of a hand drill auger. The sampling sites were selected according to the heterogeneity of the tailings considering color, texture differences, and degree of concretion or contact with the underlying soil or tailings soil-interface. The collected tailings samples were preserved in tightly sealed and marked oxygen diffusion-free polyethylene plastic bags to 
minimize dust contamination, and transported to the laboratory for sample preparation and further laboratory analyses.

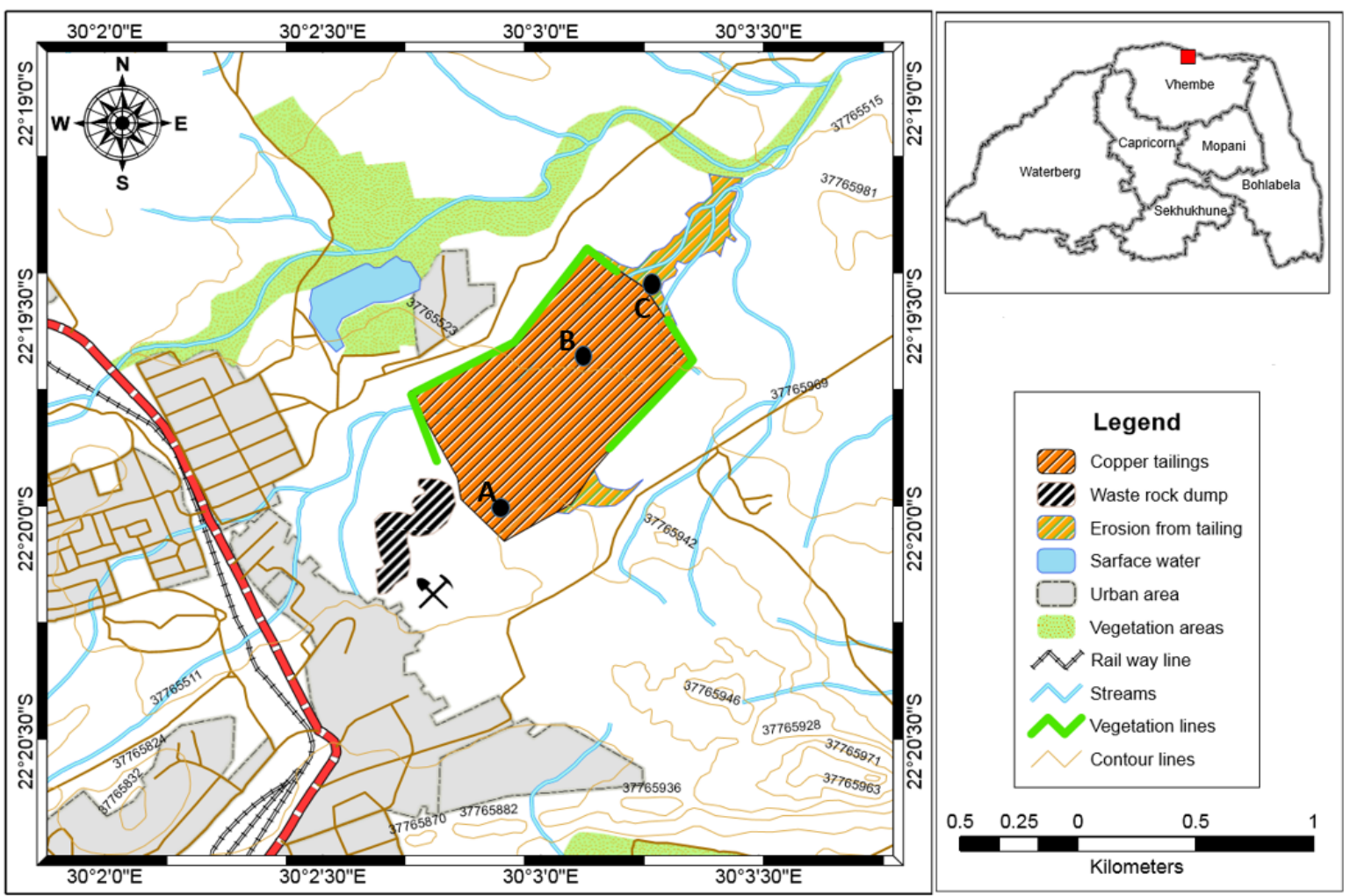

Figure 1. Location of the abandoned copper tailings dumps and the selected sampling sites in Musina, Limpopo, South Africa.

\subsection{Determination of Tailings Physical Properties}

The procured tailings samples were tested for bulk density, air-filled porosity, and moisture content. The bulk density was determined on air-dried samples using the gravimetric technique from which the air-filled porosity was calculated. The initial moisture content was determined as defined by the ASTM D 2216 [23].

\subsection{Geochemical Analysis}

\subsubsection{Paste $\mathrm{pH}$ and $\mathrm{Eh}$}

Tailings paste $\mathrm{pH}$ and Eh values were measured in a saturated soil paste using a combined Thermo Scientific instrument (reference electrode: 8102BNUWP). A saturated soil paste was prepared by adding $20 \mathrm{~mL}$ of distilled water to $20 \mathrm{~g}$ of air dried original sample (liquid:solid ratio of 1:1). The slurry was mixed for $5 \mathrm{~s}$ and left to stand for $10 \mathrm{~min}$.

\subsubsection{Bulk Chemical Element Composition}

Bulk chemical elemental composition was determined by X-ray fluorescence spectrometry (XRF) (ARL9400 XP $\mathrm{XP}^{+}$Sequential XRF with WinXRF software, Thermo Fisher, Waltham, MA, USA) at the Faculty of Natural and Agricultural Sciences, Department of Geology, University of Pretoria (Pretoria, South Africa). The tailings samples were milled in a tungsten-carbide milling pot to achieve particle sizes $<75 \mu \mathrm{m}$. The samples were dried at $100{ }^{\circ} \mathrm{C}$ and roasted at $1000{ }^{\circ} \mathrm{C}$ to determine loss on ignition (LOI) values. One gram of the samples was mixed with $6 \mathrm{~g}$ of lithium tetraborate flux and fused at $1050{ }^{\circ} \mathrm{C}$ to make a stable fused glass bead. For trace elements analysis the samples were mixed 
with PVA binder and pressed in an aluminum cup @ 10 tons. The analyzed major concentration was reported in percentage terms and trace elements in ppm. The obtained analyzed values were compared with the certified values.

\subsection{Mineralogical Analysis}

Qualitative and quantitative mineralogical analysis was performed by X-ray Diffraction Spectrometry (XRD) on the representative tailings samples within the respective tailings profiles at the University of Pretoria. The samples were analyzed using a X'Pert Pro powder diffractometer (PANalytical, Almelo, The Netherlands) in $\theta-\theta$ configuration with an $X^{\prime}$ Celerator detector and variable divergence, and fixed receiving slits with Fe filtered Co-K $\alpha$ radiation $(\lambda=1.789 \AA)$. The phases were identified using X'Pert High score plus software. The relative phase amounts (wt \%) were estimated using the Rietveld method (Autoquan Program). Scanning electron microscopy coupled with energy dispersive X-ray spectrometry (SEM-EDS) (Leo1450 SEM, Zeiss, Oberkochen, Germany, voltage was $10 \mathrm{kV}$, working distance $14 \mathrm{~mm}$ ) was performed at the Department of Electron Microscope Unit, University of Cape Town (Cape Town, South Africa) to identify and understand the distribution of secondary mineral phases present within the respective tailings samples on the tailings profiles.

\subsection{Batch Leaching Tests or Pore Water Chemistry}

Batch extractions were performed according to the standardized leaching test European norm EN 12457-2 [24]. Ten grams of the homogenized tailings samples was suspended in a $100 \mathrm{~mL}$ Mili-Q + deionized water (liquid:solid ratio of 1:10) in polyethylene plastic bottles. Sample suspensions were agitated in a horizontal shaker for $24 \mathrm{~h}$ at a temperature of $22 \pm 3{ }^{\circ} \mathrm{C}$, at $200 \mathrm{rpm}$, until a stable reading of $\mathrm{pH}$ and electrical conductivity (EC) was obtained. After shaking, and $\mathrm{pH}$ and $\mathrm{EC}$ stabilization, the batches were centrifuged at $2500 \times \mathrm{g}$ for $20 \mathrm{~min}$ and filtered through a $0.45 \mu \mathrm{m}$ membrane filter. The clear aqueous extracts were divided into two subsamples. One set of samples was acidified to $\mathrm{pH}<2$ with concentrated $\mathrm{HNO}_{3}$ for cation analysis using inductively coupled plasma-mass spectroscopy (ICP-MS) technique, and the second set of samples was left un-acidified for anion analysis by ion chromatography technique (IC). The analyses were performed in duplicates to validate the accuracy of the analytical techniques. The obtained concentrations of leachates were evaluated to assess the solubility and mobility patterns of the potentially toxic chemical species, and their potential transfer from tailings to aquatic systems. The obtained concentrations of leachates were further compared with the regulatory standards for drinking water quality as defined by the World Health Organization [25].

\section{Results and Discussion}

\subsection{Macroscopic Description and Physical Properties of Copper Tailings Samples}

The procured tailings samples are uniform, varying less in color ranging from dark to light gray at shallow and deeper depths within the respective tailings profiles, and dark to reddish brownish towards the underlying soil or soil-interface. Within tailings profiles A and B, the dark to light gray color is continuous from a shallow depth of about $2.5 \mathrm{~m}$ to deeper zones of the tailings $(\approx 3.5 \mathrm{~m})$. At the base of the respective tailings profiles $(\approx 4.5 \mathrm{~m})$, there are spots of underlying soil ranging in color from light to darkish brown, indicating mixing with soil material below the mine tailings dump. Meanwhile, in tailings profile $C$ the zone or contact with the underlying soil is reached at a shallow depth of $\approx 2.5 \mathrm{~m}$ (Figure 2). Although, the water table was not reached along the tailings profiles, there was a layer of noticeable increase resistance to drilling at the upper and shallow depth of the tailings profiles, which is attributed to the presence of consolidated layer commonly known as hardpan or cement layer, when considering the climatic condition (semi-arid) of the Musina area. A similar feature was observed at a shallow depth $(\approx 0.9 \mathrm{~m})$ of the tailings profile at the Chambishi site within the Zambian copperbelt, and was ascribed to the presence of cement or hardpan layer [11]. The presence of hardpan or cement layer in a vertical profile have been reported to generally result in increasing bulk density 
and decreasing air-filled porosity in the tailings dump [12]. The presence of cement or hardpan layers is of geochemical significance as they may incorporate large quantities of metals through adsorption and/or co-precipitation with secondary hardpan minerals, thus limiting the mobility of potentially toxic chemical species and their severity to the environment [26]. Table 1 presents some of the physical properties of the copper tailings. The relative trends for bulk density and air-filled porosity within the vertical tailings profiles are shown in Figure 2. Considering the uniform mineralogical, geochemical, and physical properties of the tailings, tailings profiles B and C were considered in this study.
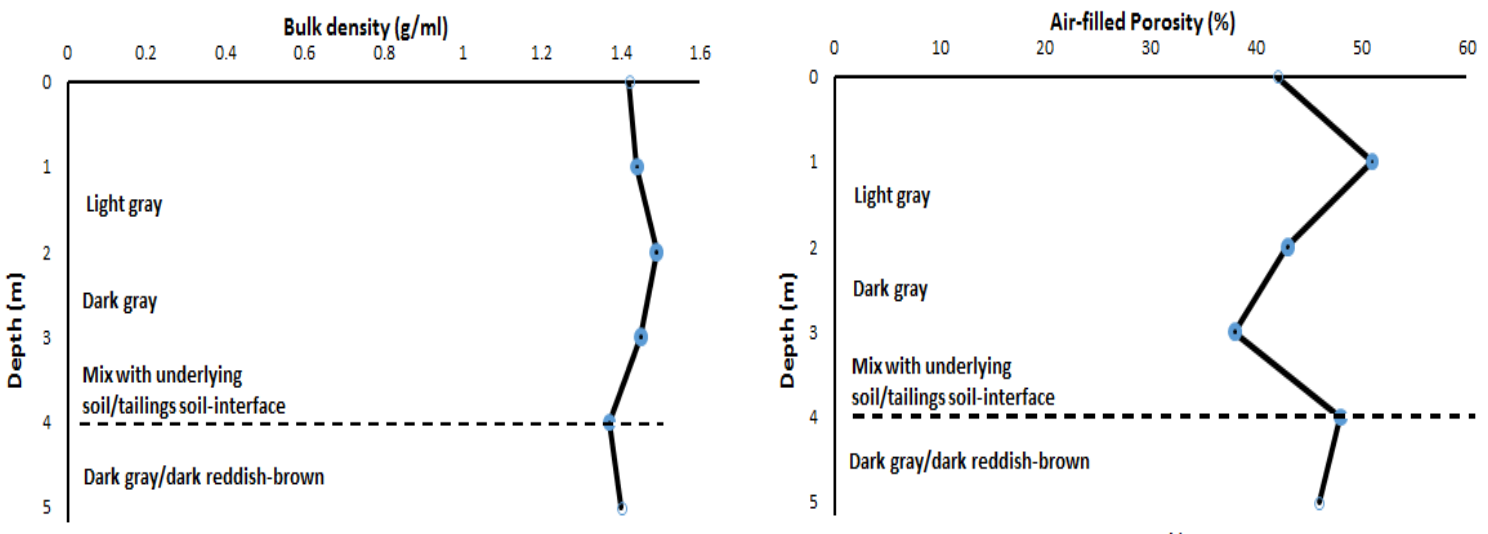

a)
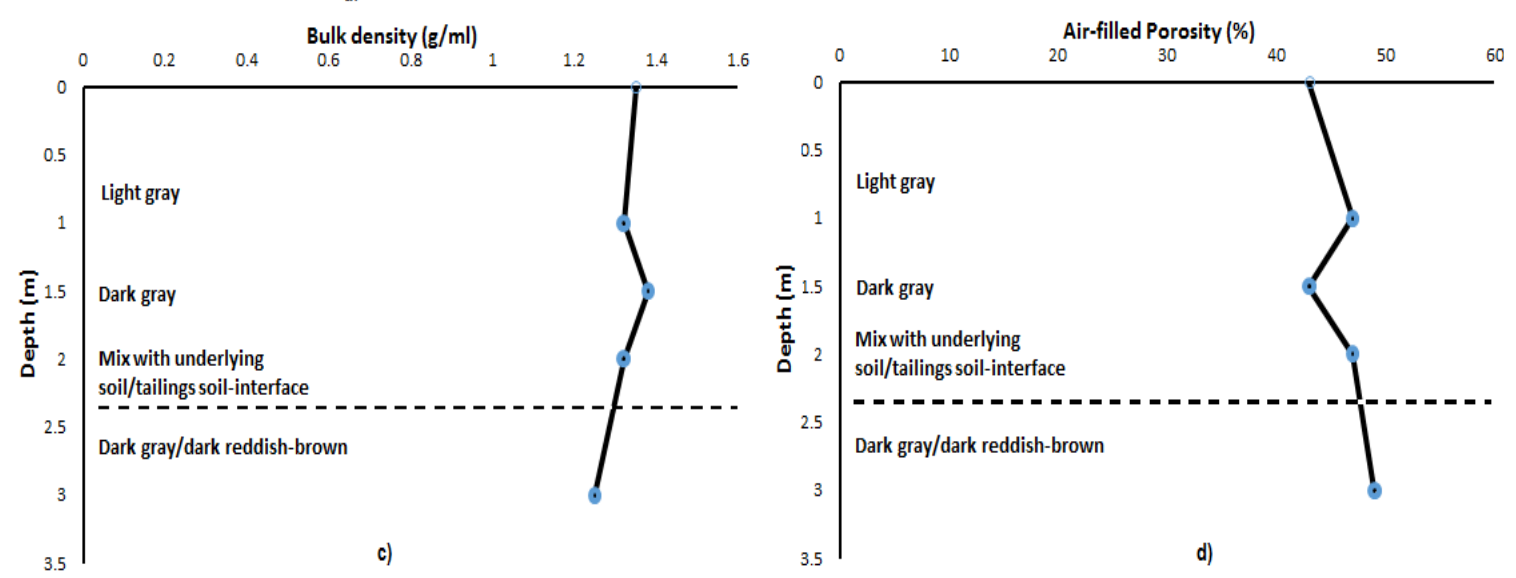

Figure 2. Simplified vertical profiles for $(\mathbf{a}, \mathbf{b})$ bulk density and air-filled porosity in tailings profile B, and $(\mathbf{c}, \mathbf{d})$ bulk density and air-filled porosity in tailings profile $\mathrm{C}$.

Table 1. Physical properties of the old copper tailings within tailings profile B.

\begin{tabular}{cccc}
\hline Depth $(\mathbf{m})$ & Bulk Density $(\mathrm{g} / \mathrm{mL})$ & Porosity $\mathbf{( \% )}$ & Moisture (\%) \\
\hline 1 & 1.42 & 42 & 0.09 \\
2 & 1.44 & 51 & 0.93 \\
3 & 1.49 & 43 & 0.43 \\
4 & 1.45 & 38 & 1.19 \\
5 & 1.37 & 50 & 1.39 \\
6 & 1.40 & 46 & 0.23 \\
\hline
\end{tabular}

As indicated, the copper tailings are characterized by high bulk density in the upper and shallow depth of the tailings profiles, reaching about $1.5 \mathrm{~g} \cdot \mathrm{mL}^{-1}$ at a depth of $\approx 2 \mathrm{~m}$ (Table 1; Figure 2a,c). A similar bulk density trend was observed at the Chambishi site within the Zambian copperbelt as reported by Sracek et al. [11]. However, the bulk density then decreases slightly to $\approx 1.4 \mathrm{~g} \cdot \mathrm{mL}^{-1}$ at about $\approx 5 \mathrm{~m}$ towards the bottom of the tailings profiles, where the mine tailings material is already 
mixing with the underlying soil. As indicated in Table 1 , the tailings material retains relatively low moisture content $(<2 \%)$. This is verified by the low air-filled porosity $(<50 \%)$ at shallow depth, although slightly increasing with tailings depth (Table 1; Figure 2b,d). The high bulk density and low air-filled porosity are coupled with relatively low initial moisture content at the upper and shallow depths of the respective tailings profiles. This could be attributed to the resistance to drilling or consolidated material which was previously referred to as cement or hardpan layer. The studied copper tailings have been exposed to oxidative weathering for a period of about 22 years, since the cessation of copper mining in 1995 [21]. However, the presence of cement or hardpan layer in the upper and shallow zones of the tailings profiles limited the penetration of oxidizing agents and oxidation products to un-oxidized tailings in the deeper zones of the respective tailings profiles.

\subsection{Mineralogical Composition within the Respective Copper Tailings Samples}

Table 2 presents the qualitative and quantitative mineralogical composition by XRD analysis. The relative mineralogical trends or patterns within the established tailings profiles are shown in Figure 3. Meanwhile, Figure 4 shows the XRD spectra along with SEM images and EDS quantification of the minerals within the tailings profiles. The mineralogical composition and patterns show low variation with depth in all the tailings profiles, and follow the order in relative abundance: quartz $>$ epidote $>$ chlorite $>$ muscovite $>$ plagioclase $>$ calcite $>$ hematite. Similar mineralogical patterns were observed by Gitari et al. [17] on the old copper tailings from the same site. A significant relative abundance of potential acid neutralizers such as alumino-silicate and traces of calcite minerals, and the absence of primary sulfidic minerals suggest a high neutralization capacity of the studied copper mine tailings. Consequently, the severe environmental impact of the mine tailings is moderated. However, quartz is the most predominant gangue mineral within the tailings profiles, and its composition increases with increasing tailings depth reaching about $42.4 \mathrm{wt} \%$ and $42.95 \mathrm{wt} \%$ at a depth of $5 \mathrm{~m}$ and $3 \mathrm{~m}$ in tailings profile $\mathrm{B}$ and $\mathrm{C}$ respectively, where the tailings are mixed with the underlying soil (Table 2; Figure 3). However, chlorite tends to decrease abruptly with increasing tailings depth within the tailings profiles (Figure 3). Calcite and hematite peaks are the only secondary minerals observed in the XRD spectra analysis. The mineralogical composition of calcite and hematite is relatively very low within the tailings samples, and their mineralogical trends or patterns are similar, and increase with increasing tailings depth, reaching $3.22 \mathrm{wt} \%$ and $2.97 \mathrm{wt} \%$, respectively within the tailings profiles (Table 2; Figure 3).

Table 2. X-ray diffraction of bulk samples from tailings profile B and C.

\begin{tabular}{|c|c|c|c|c|c|c|c|c|}
\hline $\begin{array}{l}\text { Profile B } \\
(0-2 \mathrm{~m})\end{array}$ & $\begin{array}{l}\text { Weight } \\
(\%)\end{array}$ & $3 \sigma$ Error & Profile B (2-4 m) & $\begin{array}{l}\text { Weight } \\
(\%)\end{array}$ & $3 \sigma$ Error & $\begin{array}{l}\text { Profile B } \\
\text { (5 m) }\end{array}$ & $\begin{array}{c}\text { Weight } \\
\text { (\%) }\end{array}$ & $3 \sigma$ Error \\
\hline Actinolite & 4.12 & 0.87 & Actinolite & 3.08 & 0.93 & Actinolite & 2.97 & 0.9 \\
\hline Calcite & 1.74 & 0.33 & Calcite & 1.79 & 0.36 & Calcite & 2.05 & 0.36 \\
\hline Chlorite & 17.34 & 0.84 & Chlorite & 18.87 & 0.9 & Chlorite & 17.38 & 0.93 \\
\hline Epidote & 21.64 & 0.99 & Epidote & 20.41 & 1.02 & Epidote & 21.61 & 1.05 \\
\hline Hematite & 1.58 & 0.33 & Hematite & 1.76 & 0.36 & Hematite & 1.85 & 0.33 \\
\hline Muscovite & 8.41 & 0.72 & Muscovite & 8.18 & 0.81 & Muscovite & 8.2 & 0.84 \\
\hline Plagioclase & 7.65 & 0.9 & Plagioclase & 3.98 & 0.84 & Plagioclase & 3.54 & 0.72 \\
\hline Quartz & 37.5 & 0.99 & Quartz & 41.92 & 1.08 & Quartz & 42.4 & 1.08 \\
\hline $\begin{array}{l}\text { Profile C } \\
(0-2 \mathrm{~m})\end{array}$ & $\begin{array}{l}\text { Weight } \\
\text { (\%) }\end{array}$ & $3 \sigma$ Error & $\begin{array}{c}\text { Profile C ( } 2 \mathrm{~m} \\
\text { Top-2 m Bottom) }\end{array}$ & $\begin{array}{l}\text { Weight } \\
\text { (\%) }\end{array}$ & $3 \sigma$ Error & $\begin{array}{l}\text { Profile C } \\
(3 \mathrm{~m})\end{array}$ & $\begin{array}{l}\text { Weight } \\
(\%)\end{array}$ & $3 \sigma$ Error \\
\hline Actinolite & 4.1 & 0.9 & Calcite & 2.24 & 0.39 & Actinolite & 2.47 & 0.75 \\
\hline Calcite & 2 & 0.39 & Chlorite & 16.7 & 0.84 & Calcite & 3.22 & 0.36 \\
\hline Chlorite & 16.82 & 0.87 & Epidote & 23.56 & 0.93 & Chlorite & 13.31 & 0.78 \\
\hline Epidote & 22.23 & 0.93 & Hematite & 2.28 & 0.3 & Epidote & 19.94 & 0.87 \\
\hline Hematite & 1.62 & 0.3 & Muscovite & 8.55 & 0.75 & Hematite & 2.79 & 0.3 \\
\hline Muscovite & 7.13 & 0.78 & Plagioclase & 6.59 & 0.87 & Muscovite & 8.68 & 0.69 \\
\hline Plagioclase & 3.16 & 0.75 & Quartz & 40.07 & 0.96 & Plagioclase & 6.64 & 0.75 \\
\hline Quartz & 42.94 & 1.05 & - & - & - & Quartz & 42.96 & 1.05 \\
\hline
\end{tabular}



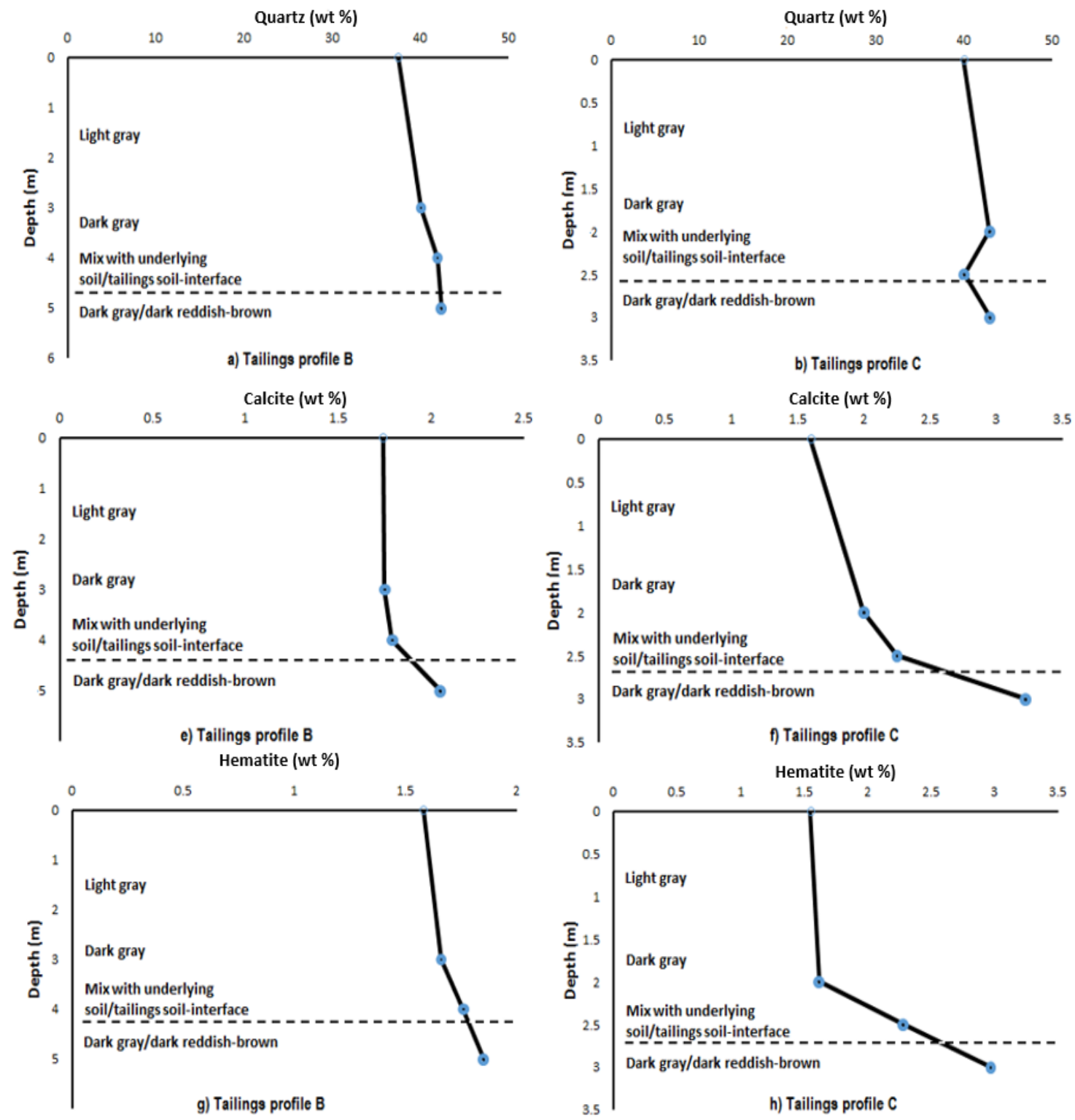

Figure 3. Mineralogical composition trends or patterns within the respective tailings profiles.

The presence of secondary minerals such as calcite and hematite within the tailings is necessary for the retention of potentially toxic chemical species by adsorption on the surface area and co-precipitation. Thus, the potential transfer of potentially toxic chemical species from tailings to the aqueous phase becomes limited [27].

To validate XRD spectra analysis, SEM-EDS analysis was performed on representative tailings samples (Figure 4). SEM microphotograph show large silver white crystals surrounded by dark minerals which are identified as quartz and Al-silicates respectively. The EDS quantification of the mineral crystals is dominated by elements of average composition, $\mathrm{O}(48.91 \mathrm{wt} \%)$, Si (28.32 wt \%), C (13.03 wt \%), Fe (11.03 wt \%), Al (6.63 wt \%), Na (4.92 wt \%), Mg (3.39 wt \%), and substantial amounts of $\mathrm{Ca}(0.98 \mathrm{wt} \%)$. High quantities of $\mathrm{Si}, \mathrm{O}, \mathrm{Al}, \mathrm{Na}$, and $\mathrm{Mg}$, attest to the high quantities of quartz and alumino-silicate minerals. Simultaneously, the quantities of Fe and $\mathrm{Ca}$, confirm the traces of calcite and hematite secondary minerals respectively. 

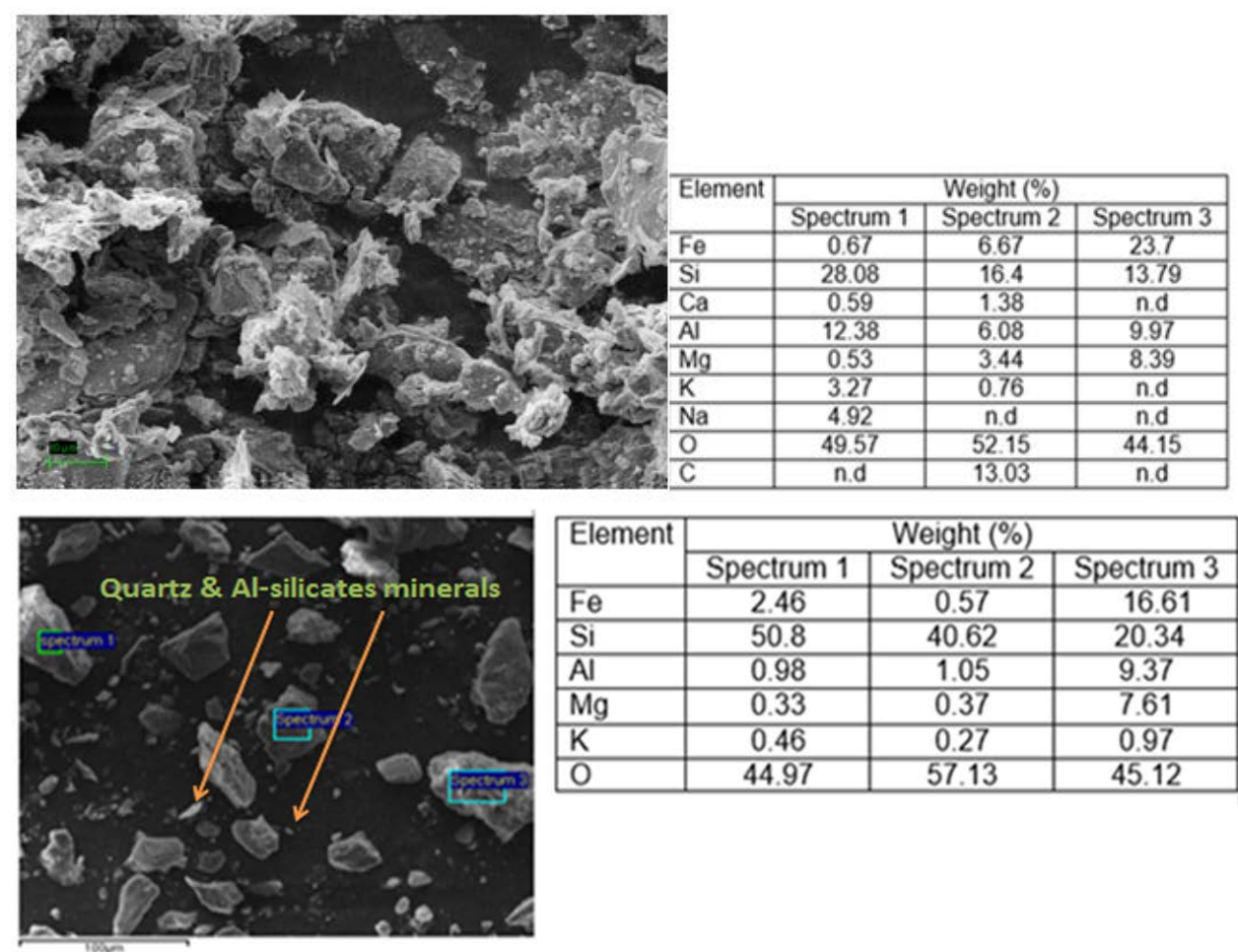

\begin{tabular}{|l|c|c|c|}
\hline \multirow{2}{*}{ Element } & \multicolumn{3}{|c|}{ Weight (\%) } \\
\cline { 2 - 4 } & Spectrum 1 & Spectrum 2 & Spectrum 3 \\
\hline $\mathrm{Fe}$ & 2.46 & 0.57 & 16.61 \\
\hline $\mathrm{Si}$ & 50.8 & 40.62 & 20.34 \\
\hline $\mathrm{Al}$ & 0.98 & 1.05 & 9.37 \\
\hline $\mathrm{Mg}$ & 0.33 & 0.37 & 7.61 \\
\hline $\mathrm{K}$ & 0.46 & 0.27 & 0.97 \\
\hline $\mathrm{O}$ & 44.97 & 57.13 & 45.12 \\
\hline
\end{tabular}

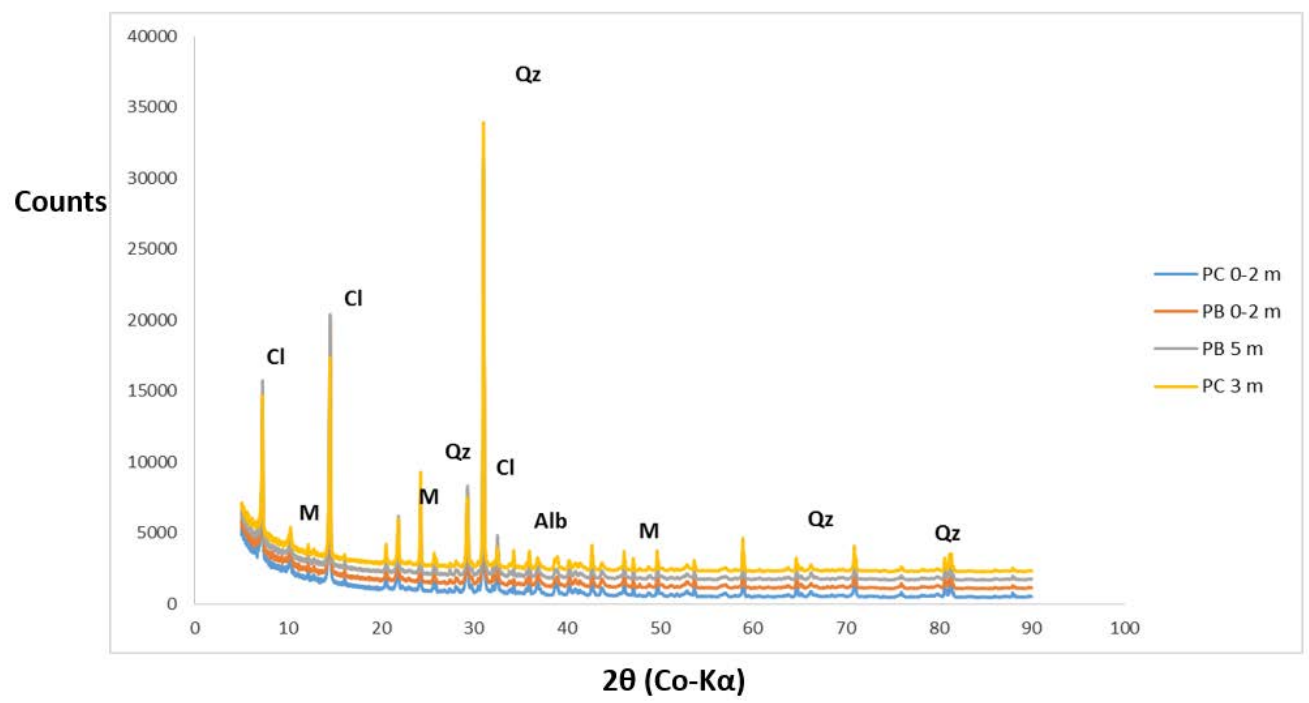

Figure 4. Representative scanning electron microscopy-energy dispersive spectroscopy (SEM-EDS) under 10 and $100 \mu \mathrm{m}$ magnification and X-ray diffraction (XRD) patterns within tailings profile $\mathrm{C}$ at a depth of $2.5 \mathrm{~m}$. Abbreviations: Qz-quartz, $\mathrm{Cl}$-clinochlore, $\mathrm{M}$-muscovite, Alb-albite, n.d-not detected.

\subsection{Tailings Paste $\mathrm{pH}$ and Eh}

Figure 5 depicts paste $\mathrm{pH}$ values and patterns within the tailings profiles. The tailings paste $\mathrm{pH}$ values are medium alkaline (i.e., 7.97-8.37). Similar paste $\mathrm{pH}$ values were observed in neutral, low sulfide/high carbonate tailings impoundment in eastern Slovakia [9]. The medium alkaline $\mathrm{pH}$ condition of the tailings could be ascribed to the dominant potential acid-neutralizers or $\mathrm{pH}$ buffering minerals such as alumino-silicate minerals and traces of carbonate (i.e., calcite) present within the tailings system. Nevertheless, as expected the measured paste Eh values are lower in the tailings profiles (Eh is equal from -90.8 to $-61.9 \mathrm{mV}$ ) indicating a more reducing or anoxic geochemical environment (Table 3). 

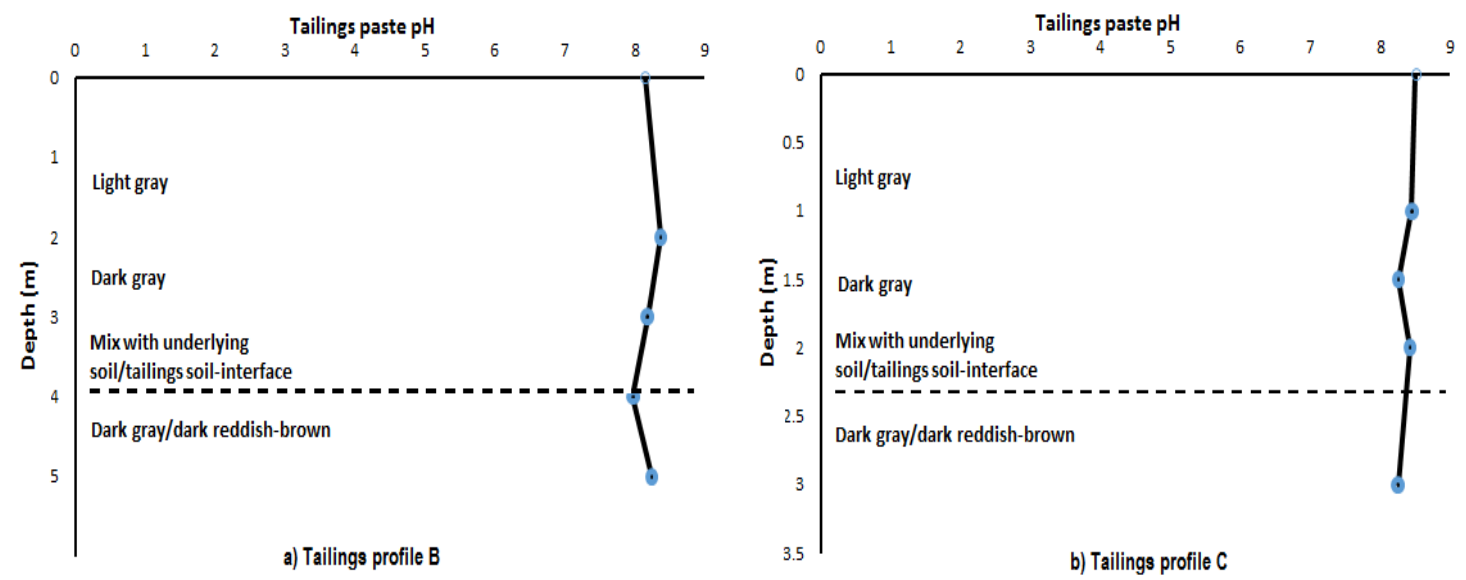

Figure 5. Tailings paste $\mathrm{pH}$ content within the respective tailings profiles.

\subsection{Bulk Chemical Elemental Composition within the Tailings Profiles}

Table 3 shows the concentration of major and trace elements within the tailings profiles. The concentration of potentially toxic chemical species was further compared with the South African soil quality guidelines for all land uses (2012). However, the bulk chemical element concentration for major and trace elements varies less in the tailings profiles. The major elements are in the following order of quantities; $\mathrm{Si}>\mathrm{Al}>\mathrm{Fe}>\mathrm{Ca}>\mathrm{Mg}>\mathrm{K}>\mathrm{Na}$ (Table 3). The major element constituents within the tailings profiles agree very well with the mineralogical composition of the tailings. This shows that quartz and alumino-silicates are the most abundant minerals within the established tailings profiles (Table 2). The concentration of silica increases with the quartz content which is the main carrier of $\mathrm{Si}$ in the tailings profiles (Table 2; Figure 6). The presence of other major oxides such as $\mathrm{Fe}, \mathrm{Mg}, \mathrm{Ca}, \mathrm{K}$, and Na correspond obviously to the moderate presence of epidote, chlorite, muscovite, calcite, and hematite as the main elemental constituent, and identified in the XRD spectra analysis (Table 2; Figure 6).

Table 3. Total concentration for major and trace elements within tailings profile B.

\begin{tabular}{|c|c|c|c|c|c|c|}
\hline Paste pH & 8.14 & 8.37 & \multicolumn{2}{|c|}{8.18} & 7.97 & 8.24 \\
\hline $\mathrm{Eh}(\mathrm{mV})$ & -71.3 & -83.9 & \multicolumn{2}{|c|}{-73.3} & -61.9 & -77.2 \\
\hline Depth (m) & $0-1$ & $1-2$ & \multicolumn{2}{|c|}{$2-3$} & $3-4$ & $4-5$ \\
\hline Colour & Dark gray & Light/dark gray & \multicolumn{2}{|c|}{ Light/dark gray } & Light/dark gray & Dark-reddish brown \\
\hline \multicolumn{7}{|l|}{ wt $\%$} \\
\hline $\mathrm{SiO}_{2}$ & 58.1176 & 58.1431 & \multicolumn{2}{|c|}{58.2518} & 58.4938 & 58.5819 \\
\hline $\mathrm{TiO}_{2}$ & 0.798 & 0.9266 & \multicolumn{2}{|c|}{0.9151} & 0.9105 & 0.9079 \\
\hline $\mathrm{Al}_{2} \mathrm{O}_{3}$ & 14.1711 & 13.9807 & \multicolumn{2}{|c|}{13.9559} & 13.9314 & 13.564 \\
\hline $\mathrm{Fe}_{2} \mathrm{O}_{3}$ & 10.5766 & 11.3313 & \multicolumn{2}{|c|}{11.2364} & 11.0953 & 11.7616 \\
\hline $\mathrm{MnO}$ & 0.0502 & 0.0524 & \multicolumn{2}{|c|}{0.0544} & 0.0537 & 0.0556 \\
\hline $\mathrm{MgO}$ & 2.6372 & 2.4388 & \multicolumn{2}{|c|}{2.5485} & 2.6219 & 2.66 \\
\hline $\mathrm{CaO}$ & 7.3781 & 7.6648 & \multicolumn{2}{|c|}{7.5943} & 7.3809 & 7.2605 \\
\hline $\mathrm{Na}_{2} \mathrm{O}$ & 0.3797 & 0.324 & \multicolumn{2}{|c|}{0.3671} & 0.361 & 0.4474 \\
\hline $\mathrm{K}_{2} \mathrm{O}$ & 1.0167 & 0.8587 & \multicolumn{2}{|c|}{0.8272} & 0.8588 & 0.8066 \\
\hline LOI & 3.93 & 3.23 & \multicolumn{2}{|c|}{2.96} & 3.08 & 2.8908 \\
\hline TOTAL & 99.5507 & 99.509 & \multicolumn{2}{|c|}{99.1803} & 99.2741 & 99.4133 \\
\hline ppm & 0-1 m & $1-2 \mathrm{~m}$ & $2-3 \mathrm{~m}$ & 3-4 m & $4-5 \mathrm{~m}$ & $\begin{array}{c}\text { South African Soil } \\
\text { Quality Guidelines [28] }\end{array}$ \\
\hline $\mathrm{Cu}$ & 1063 & 862 & 602 & 816 & 515 & 16 \\
\hline $\mathrm{Ni}$ & 36 & 16 & 20 & 35 & 14 & 91 \\
\hline $\mathrm{Pb}$ & - & - & - & - & - & 20 \\
\hline $\mathrm{Zn}$ & 25 & 13 & 15 & 24 & 10 & 240 \\
\hline $\mathrm{Zr}$ & 151 & 223 & 187 & 256 & 123 & - \\
\hline $\mathrm{Sr}$ & 236 & 192 & 197 & 252 & 133 & - \\
\hline
\end{tabular}



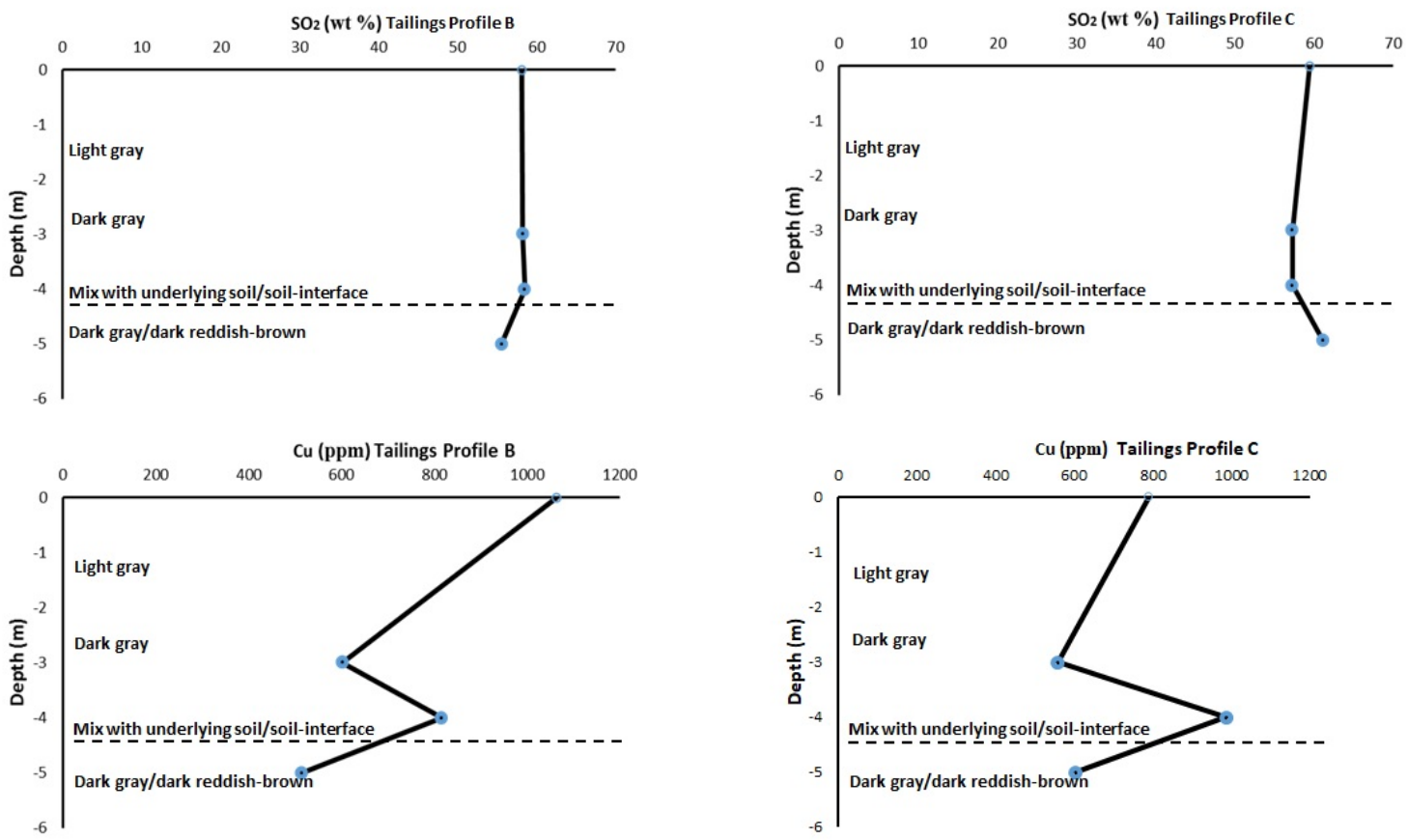

Figure 6. Relative concentration trends or patterns for selected potentially toxic elements with tailings depth.

However, the relative abundance of potentially toxic chemical species is in the following order of quantity; $\mathrm{Cu}>\mathrm{Sr}>\mathrm{Zr}>\mathrm{Ni}>\mathrm{Zn}$. Copper has the highest concentration, reaching $1063 \mathrm{ppm}$ at the upper zone of the tailings profile (Table 3; Figure 6). The elevated concentration of copper (Cu) could be attributed to chalcopyrite, chalcocite, and bornite which are considered as primary minerals from which copper $(\mathrm{Cu})$ was recovered during past copper mining activities in Musina [21]. However, the elevated concentration of copper $(\mathrm{Cu})$ decreases moderately with depth, reaching $515 \mathrm{ppm}$ where the tailings are already mixed with the underlying soil or soil-interface (Figure 6). Nevertheless, when compared with the Canadian soil quality guidelines for the protection of the environment and industrial land use, copper $(\mathrm{Cu})$ exceeds the guideline values by a large magnitude (Table 3). Elevated concentrations of copper $(\mathrm{Cu})$ were also reported within the neutral, low-sulfide/high carbonate tailings at eastern Slovakia, and Chambishi site within the Zambian copperbelt, respectively $[9,11]$.

When tailings are in contact with infiltrating rainwater, the elevated concentration of potentially toxic chemical species such as copper $(\mathrm{Cu})$ in the tailings may leach to the adjacent surface and groundwater systems, thereby disturbing aquatic life, and further impacting the health of humans depending on groundwater sources for survival. Nevertheless, moderate concentration of $\mathrm{Zr}$, along with traces of $\mathrm{Ni}$ and $\mathrm{Zn}$ were also noticeable within the tailings profiles, although these concentrations did not exceed the South African soil quality guidelines for all land uses (Table 3).

\subsection{Pore-Water Chemistry, Solubility, and Mobility Patterns for Potentially Toxic Chemical Species with Tailings Depth}

Water soluble elements within the tailings are considered as more useful indicators of their potential hazards to the surrounding environment than total concentrations of the elements, as water soluble elements are implicitly mobile and bioavailable [9]. The potential transfer of potentially toxic chemical species from tailings to the aqueous phase was evaluated using the standardized leaching test EN 12457-2 [24]. Romero et al. [7] successfully used a similar approach on abandoned $\mathrm{Pb}$ and Zn flotation tailings at "El Fraile" impoundments in Taxco, central-southern Mexico. The obtained leachates concentration of the potentially toxic chemical species and sulfates were used to evaluate the geochemical processes controlling the relative solubility and mobility of potentially toxic chemical 
species within the established tailings profiles, and further assess the potential transfer of potentially toxic chemical species from tailings to the aqueous phase. Moreover, the obtained leachates concentration of potentially toxic chemical species was compared with the limit guideline values for drinking water quality prescribed by the World Health Organization [25].

The physicochemical parameters, relative percentage leach, or mobility of the potentially toxic chemical species, saturation index of mineral phases, and percentages of main species within pore-water solution calculated by MINTEQA2 are shown in Tables 4-6 respectively. The results give a simulation of the chemical constituents that are likely to be present in the generated plume after a rainfall event when the tailings interact with rainfall with the potential risk to surface and groundwater contamination. The tailings leachates have a medium alkaline $\mathrm{pH}$ condition (8.36-8.41). The tailings leachate $\mathrm{pH}$ is uniform and constant with tailings depth, and corresponds very well with the tailings paste $\mathrm{pH}(7.97-8.37)$ (Figure 5). The medium alkaline tailings leachates $\mathrm{pH}$ could be ascribed to the neutralization potentials of the dominant alumino-silicate minerals, traces of carbonates as calcite, and the absence of sulfide minerals (Table 2) as indicated in the XRD spectra analysis. Electrical conductivity increased with increasing tailings depth ranging from 156.5 to $364 \mu \mathrm{S} / \mathrm{cm}$. On the other hand, the total dissolved solids (TDS) is uniform and constant throughout the tailings depth, averaging $18.8 \mathrm{mg} / \mathrm{L}$. The order of relative abundance of average dissolved concentration of water soluble elements is as follows: $\mathrm{Al}>\mathrm{Fe}>\mathrm{Cu}>\mathrm{Mn}>\mathrm{Zn}>\mathrm{Ni}>\mathrm{Pb}$ (Table 5). This observed pattern does not agree with the order of their total solid-phase concentration ( $\mathrm{Al}>\mathrm{Fe}>\mathrm{Cu}>\mathrm{Ni}>\mathrm{Zn}$ ) (Table 3). The dissolved concentrations of $\mathrm{Al}$ and $\mathrm{Fe}$ are high at the upper and shallow depth of the tailings profiles peaking at $\approx 235.85$ and $143.52 \mu \mathrm{g} / \mathrm{L}$ respectively (Table 5; Figure 7). However, the dissolved concentration of $\mathrm{Al}$ and Fe decreases with tailings depth, reaching $\approx 157.86$ and $100.8 \mu \mathrm{g} / \mathrm{L}$ respectively at the point where the tailings are in contact with the underlying soil. This could indicate that $\mathrm{Al}$ and Fe show similar trends or patterns of solubility and mobility within the tailings profiles which tend to decrease with increasing tailings depth. The precipitation and dissolution of alumino-silicates bearing $\mathrm{Al}$ and Fe such as epidote and muscovite under medium alkaline $\mathrm{pH}$ condition are the main solubility and mobility control for $\mathrm{Fe}$ and $\mathrm{Al}$ species in the tailings leachates. In comparison with WHO standards for drinking water quality [25], only Al concentration is above the permissible limit ( $\leq 100 \mu \mathrm{g} / \mathrm{L})$ in the tailings leachates (Table 5). The dissolved concentration of potentially toxic chemical species is very low in the aqueous phase of the tailings, and follows the order: $\mathrm{Cu}(20.21-47.9 \mu \mathrm{g} / \mathrm{L})>\mathrm{Zn}(0.88-1.8 \mu \mathrm{g} / \mathrm{L})$ $>\mathrm{Ni}(0.54-0.72 \mu \mathrm{g} / \mathrm{L})>\mathrm{Pb}(0.27-0.34 \mu \mathrm{g} / \mathrm{L})$ (Table 5). The dissolved concentration of $\mathrm{Cu}$ follows a similar trend or pattern as $\mathrm{Al}$ and Fe which is high at the upper and shallow depths of the tailings profiles peaking at approximately $\approx 25.65 \mu \mathrm{g} / \mathrm{L}$. Cu decreases with increasing tailings depth reaching a concentration maxima $(\approx 20.21 \mu \mathrm{g} / \mathrm{L})$ at the tailings-soil interface (Figure 7$)$. The low water-soluble concentration of dissolved potentially toxic chemical species in the aqueous phase of the tailings could be attributed to: (a) the medium alkaline $\mathrm{pH}$ condition of the tailings leachates (8.36-8.46); (b) adsorption and co-precipitation on secondary resistance minerals such as hematite identified during mineralogical analysis; hematite is a very stable mineral, resistant to weathering or any change in the redox condition, and has been reported to retain a large quantity of potentially toxic chemical species [7,11]; and (c) the absence of soluble sulfide minerals hosting these potentially toxic chemical species within the tailings systems. Dold [29] documented that the solubility of many potentially toxic chemical species increases with decreasing or acidic $\mathrm{pH}$, and more dissolved potentially toxic chemical species become more soluble, mobile, and bioavailable to the adjacent receiving surface and groundwater systems. 

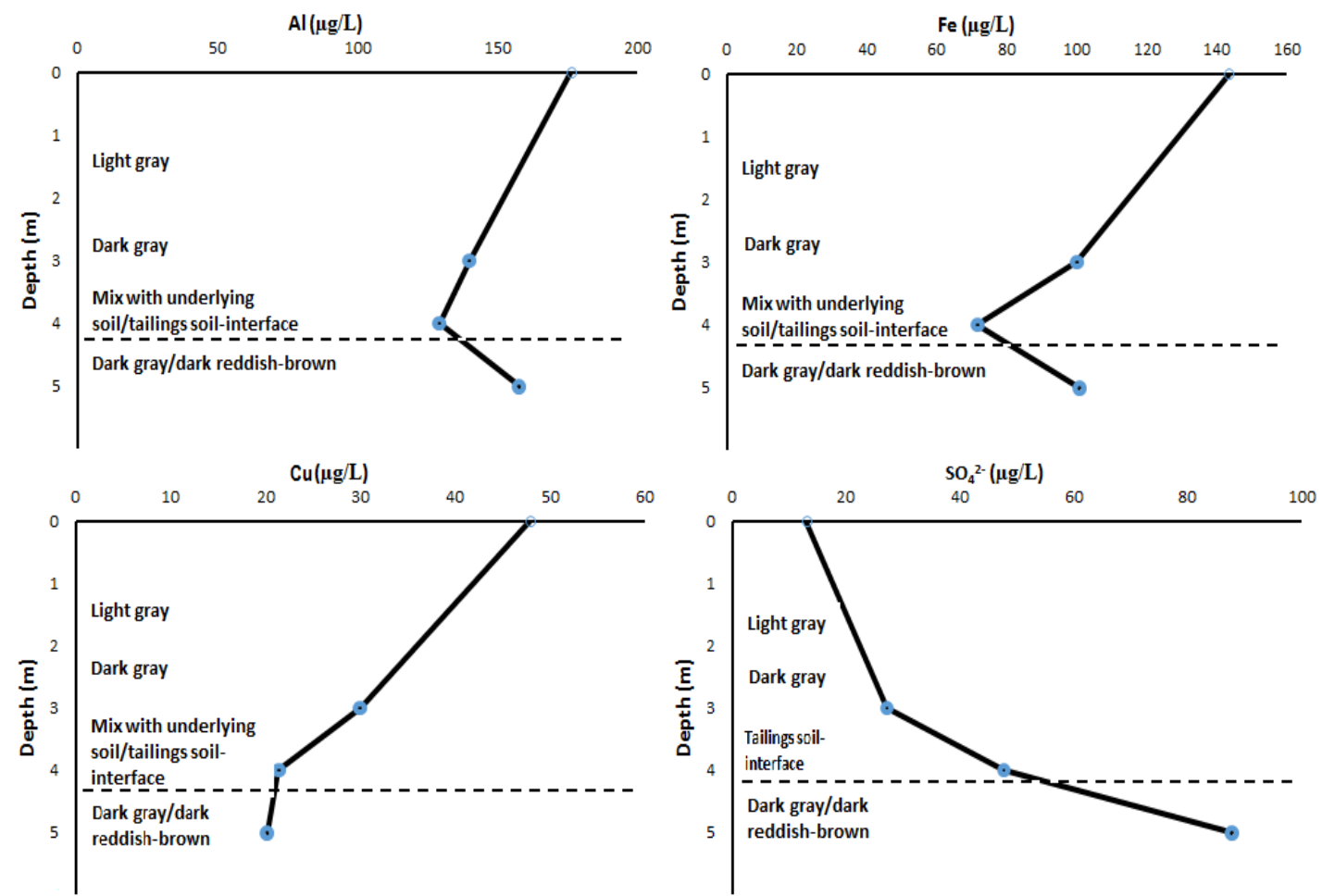

Figure 7. Representative tailings leachate concentration of selected metals as a function of depth within tailings profile $\mathrm{B}$.

Table 4. Extractabilities of potentially toxic chemical species expressed as the percentage leach of the total solid phase concentration within tailings profile $\mathrm{B}$.

\begin{tabular}{ccccccc}
\hline \multirow{2}{*}{ Sample Name } & \multicolumn{6}{c}{ Relative Mobility or \% Leach of Chemical Species } \\
\cline { 2 - 7 } & $\mathbf{C u}$ & Co & Ni & Cd & Zn & Pb \\
\hline PB $(0-2 \mathrm{~m})$ & 0.006 & n.m & 0.081 & n.m & 0.005 & n.m \\
PB $(2-4 \mathrm{~m})$ & 0.003 & n.m & 0.003 & n.m & 0.015 & n.m \\
PB $(4-5 \mathrm{~m})$ & 0.005 & n.m & 0.006 & n.m & 0.027 & n.m \\
\hline
\end{tabular}

n.m-not measured due to low detection limit of the solid phase.

However, a better indication for the mobility of potentially toxic chemical species can be obtained by the estimation of percentages leached of their total concentration within the tailings (Table 4). Based on the calculated mobility percentages, the potentially toxic chemical species show the lowest mobility within the aqueous phase (Ni $0.081 \%$, $\mathrm{Cu} 0.006 \%$, and $\mathrm{Zn} 0.05 \%$ ). This observed pattern confirms the low concentration of dissolved potentially toxic chemical species in the tailings leachates and pore-water solution. This indicates that the potential transfer load of potentially toxic chemical species from tailings to the adjacent receiving surface and groundwater systems is very low.

Table 6 corroborates the low dissolved concentration, and low solubility and mobility of the potentially toxic chemical species in the tailings leachates as calculated by MINTEQA2. The tailings leachates are oversaturated with cuprite $(\mathrm{SI}=1.403-5.488)$, and below saturation regarding oxyhydroxide minerals (Table 6). This shows that the formation of secondary cuprite $\left(\mathrm{Cu}_{2} \mathrm{O}\right)$ is the other important factor controlling the solubility and mobility for $\mathrm{Cu}$ ions in the tailings profiles. The prevailing species of $\mathrm{Cu}$ are free $\mathrm{Cu}^{2+}$ ion $(100 \%)$ and sulfate complexes $\mathrm{CuSO}_{3}{ }^{-}(98.79 \%)$ in the tailings profiles suggesting that the number of sulfate containing compounds such as sulfuric acid used during past copper mining activities to enhance ore separation is the other solubility and mobility controlling phase for $\mathrm{Cu}$ in the tailings leachates. However, the prevailing species for other potentially toxic chemical species are free $\mathrm{Co}^{2+}(\approx 96.85 \%), \mathrm{Ni}^{2+}(\approx 97.99 \%)$, and $\mathrm{Cd}^{2+}$ 
$(\approx 98.84 \%)$ (Table 6 ) indicating the absence of soluble sulfide complexes which are the main carrier for these potentially toxic chemical species. This observed pattern further verified the low dissolved concentrations and low solubility and mobility for $\mathrm{Co}, \mathrm{Ni}$, and $\mathrm{Cd}$ in the tailings profiles. Nonetheless, the dissolved concentration of sulfate in the tailings leachates is high compared to other anions, and increases abruptly with tailings depth within the tailings profiles peaking at an average of $87.76 \mu \mathrm{g} / \mathrm{L}$ at the point of contact between the tailings and underlying soil (Table 5; Figure 7). The high dissolved concentration of sulfates could be ascribed to the sulfate complexes calculated by MINTEQA2 which are connected to the sulfuric acid used to enhance ore separation during beneficiation and mineral processing of the mined copper ore.

Table 5. Physicochemical parameters of tailings pore-water for tailings profile B.

\begin{tabular}{|c|c|c|c|c|c|}
\hline Bulk Chemical Composition & Units & PB (0-2 m) & PB (2-4 m) & PB (4-5 m) & WHO [25] \\
\hline $\mathrm{pH}_{\mathrm{H} 20}$ & - & $8.46 \pm 0.098$ & $8.36 \pm 0.021$ & $8.41 \pm 0.04$ & - \\
\hline EC & $\mu \mathrm{S} / \mathrm{cm}$ & $156.5 \pm 16.82$ & $312 \pm 7.07$ & $364 \pm 1.44$ & - \\
\hline TDS & $\mathrm{mg} / \mathrm{L}$ & $18.8 \pm 0.07$ & $18.75 \pm 0.06$ & $18.85 \pm 0.06$ & - \\
\hline $\mathrm{Al}$ & $\mu \mathrm{g} / \mathrm{L}$ & $176.23 \pm 59.67$ & $129.37 \pm 25$ & $157.86 \pm 0.26$ & $\leq 100$ \\
\hline $\mathrm{Fe}$ & $\mu \mathrm{g} / \mathrm{L}$ & $143.51 \pm 95.58$ & $71.65 \pm 2.99$ & $100.83 \pm 1.47$ & $\leq 1000-3000$ \\
\hline $\mathrm{Ti}$ & $\mu \mathrm{g} / \mathrm{L}$ & $1.18 \pm 0.15$ & $0.78 \pm 0.14$ & $0.87 \pm 0.12$ & - \\
\hline $\mathrm{V}$ & $\mu \mathrm{g} / \mathrm{L}$ & $1.18 \pm 0.04$ & $0.63 \pm 0.08$ & $1.02 \pm 0.03$ & - \\
\hline $\mathrm{Cr}$ & $\mu g / L$ & $0.90 \pm 0.26$ & $0.60 \pm 0.04$ & $1.13 \pm 0.04$ & $\leq 50$ \\
\hline $\mathrm{Mn}$ & $\mu \mathrm{g} / \mathrm{L}$ & $17.68 \pm 2.40$ & $37.10 \pm 8.07$ & $16.63 \pm 1.80$ & $\leq 500$ \\
\hline Co & $\mu \mathrm{g} / \mathrm{L}$ & $0.09 \pm 0.02$ & $0.08 \pm 0.01$ & $0.09 \pm 0.01$ & $\leq 500$ \\
\hline $\mathrm{Ni}$ & $\mu \mathrm{g} / \mathrm{L}$ & $0.54 \pm 0.01$ & $0.72 \pm 0.08$ & $0.62 \pm 0.02$ & $\leq 70$ \\
\hline $\mathrm{Cu}$ & $\mu \mathrm{g} / \mathrm{L}$ & $47.9 \pm 4.27$ & $21.43 \pm 1.74$ & $20.21 \pm 0.01$ & $\leq 2000$ \\
\hline $\mathrm{Zn}$ & $\mu \mathrm{g} / \mathrm{L}$ & $0.88 \pm 0.21$ & $1.54 \pm 1.02$ & $1.8 \pm 0.52$ & $\leq 5000$ \\
\hline As & $\mu \mathrm{g} / \mathrm{L}$ & $0.31 \pm 0.22$ & $0.22 \pm 0.01$ & $0.29 \pm 0.12$ & $\leq 10$ \\
\hline Se & $\mu \mathrm{g} / \mathrm{L}$ & $17.41 \pm 1.23$ & $20.93 \pm 1.51$ & $10.81 \pm 2.88$ & - \\
\hline $\mathrm{Sr}$ & $\mu \mathrm{g} / \mathrm{L}$ & $57.54 \pm 1.96$ & $123.88 \pm 10.1$ & $106.33 \pm 4.22$ & - \\
\hline Mo & $\mu \mathrm{g} / \mathrm{L}$ & $41.4 \pm 2.9$ & $59.44 \pm 2.98$ & $66.11 \pm 1.22$ & - \\
\hline $\mathrm{Cd}$ & $\mu \mathrm{g} / \mathrm{L}$ & $0.02 \pm 0.01$ & 0.01 & $0.02 \pm 0.01$ & $\leq 10$ \\
\hline $\mathrm{Ba}$ & $\mu \mathrm{g} / \mathrm{L}$ & $13.1 \pm 1.86$ & $19.02 \pm 1.98$ & $16.17 \pm 0.88$ & - \\
\hline $\mathrm{Hg}$ & $\mu \mathrm{g} / \mathrm{L}$ & $0.28 \pm 0.08$ & $0.15 \pm 0.07$ & $0.10 \pm 0.02$ & $\leq 6$ \\
\hline $\mathrm{Pb}$ & $\mu \mathrm{g} / \mathrm{L}$ & $0.27 \pm 0.08$ & $0.28 \pm 0.09$ & $0.34 \pm 0.01$ & $\leq 5-10$ \\
\hline $\mathrm{Ca}$ & $\mathrm{mg} / \mathrm{L}$ & $26.71 \pm 0.7$ & $55.515 \pm 3.92$ & $30.75 \pm 2.07$ & $\leq 150$ \\
\hline K & $\mathrm{mg} / \mathrm{L}$ & $9.09 \pm 1.35$ & $9.11 \pm 1.9$ & $8.45 \pm 1.92$ & - \\
\hline $\mathrm{Mg}$ & $\mathrm{mg} / \mathrm{L}$ & $4.88 \pm 0.04$ & $12.67 \pm 1.77$ & $8.01 \pm 0.41$ & $\leq 70$ \\
\hline $\mathrm{Na}$ & $\mathrm{mg} / \mathrm{L}$ & $2.08 \pm 0.13$ & $4.4 \pm 0.2$ & $4.88 \pm 0.11$ & $\leq 200$ \\
\hline S & $\mathrm{mg} / \mathrm{L}$ & $15.71 \pm 0.03$ & $55.94 \pm 2.24$ & $25.56 \pm 1.98$ & - \\
\hline $\mathrm{SO}_{4}{ }^{2-}$ & ppm & $13.02 \pm 3.16$ & $47.74 \pm 0.93$ & $87.76 \pm 4.463$ & $\leq 500$ \\
\hline $\mathrm{Cl}^{-}$ & ppm & $2.106 \pm 0.35$ & $16.93 \pm 0.83$ & $24.38 \pm 0.44$ & $\leq 300$ \\
\hline
\end{tabular}

Table 6. Saturation index of mineral phases (SI) and percentages of main species calculated by MINTEQA2 within the tailings pore water.

\begin{tabular}{ccc}
\hline Saturation Index & Profile B & Profile C \\
\hline $\mathrm{Cd}(\mathrm{OH})_{2}(\mathrm{~s})$ & -7.074 & -3.06 \\
$\mathrm{CoO}(\mathrm{s})$ & -6.092 & -5.605 \\
$\mathrm{Cr}(\mathrm{OH})_{2}(\mathrm{~s})$ & -5.33 & -5.022 \\
$\mathrm{Cuprite}$ & 5.488 & 1.403 \\
$\mathrm{Fe}(\mathrm{OH})_{2}(\mathrm{am})$ & -2.78 & -2.453 \\
$\mathrm{Ni}(\mathrm{OH})_{2}(\mathrm{~s})$ & -4.611 & -4.06 \\
$\mathrm{Quartz}$ & -2.925 & -2.909 \\
$\mathrm{Zn}(\mathrm{OH})_{2}(\mathrm{am})$ & -4.171 & -3.535 \\
\hline $\mathrm{Main} \mathrm{Species} \mathrm{( \% )}$ & Profile B & Profile C \\
\hline $\mathrm{Cd}^{2+}$ & - & - \\
$\mathrm{CdOH}^{+}$ & 98.845 & 97.869 \\
$\mathrm{CdOH}^{+}$ & 1.145 & 2.013 \\
\hline
\end{tabular}


Table 6. Cont.

\begin{tabular}{ccc}
\hline Saturation Index & Profile B & Profile C \\
\hline $\mathrm{Co}$ & - & - \\
$\mathrm{Co}^{2+}$ & 96.854 & 94.082 \\
$\mathrm{CoOH}^{+}$ & 2.817 & 4.861 \\
$\mathrm{Co}(\mathrm{OH})_{2}(\mathrm{aq})$ & 0.328 & 1.007 \\
\hline $\mathrm{Cr}$ & - & - \\
$\mathrm{Cr}^{2+}$ & 0.084 & 0.047 \\
$\mathrm{CrOH}^{+}$ & 99.916 & 99.953 \\
\hline $\mathrm{Cu}^{+}$ & - & - \\
$\mathrm{Cu}^{+}$ & 100 & 1.21 \\
$\mathrm{CuSO}_{3}{ }^{-}$ & $\mathrm{N} / \mathrm{A}$ & 98.79 \\
\hline $\mathrm{Fe}^{2+}$ & - & - \\
$\mathrm{Fe}^{2+}$ & 94.508 & 90.637 \\
$\mathrm{FeOH}^{+}$ & 5.485 & 9.343 \\
\hline $\mathrm{Ni}^{2+}$ & - & - \\
$\mathrm{Ni}^{2+}$ & 97.992 & 96.181 \\
$\mathrm{NiOH}^{+}$ & 1.798 & 3.135 \\
$\mathrm{Ni}\left(\mathrm{OH}_{2}(\mathrm{aq})\right.$ & 0.21 & 0.65 \\
\hline
\end{tabular}

\section{Summary and Conclusions}

An assessment on the mobility patterns and attenuation dynamics of potentially toxic chemical species within copper tailings profiles has been carried out. The tailings were characterized by high bulk density and low air-filled porosity, along with low moisture content at the upper and shallow depths of the tailings profiles. Simultaneously, the solid phase content of potentially toxic chemical species ( $\mathrm{Cu}$ 602-1063 ppm > Ni 20-36 ppm > Zn 15-25 ppm) was high at the upper and shallow depths of the tailings profiles, and decreased with increasing tailings depth. The physical properties of the tailings have been significant in the retention and mobility attenuation of the potentially toxic chemical species within the studied tailings profiles. The concentration of $\mathrm{Cu}$ exceeded the South African soil quality guidelines for all land uses, consequently this could present a potential risk for the adjacent aquatic systems during leaching, mainly when the tailings become in contact with infiltrating rain-water, and furthermore the land could become unsuitable for agricultural purposes. The relative abundance of the identified mineral peaks followed the order of quantity: quartz $>$ epidote $>$ chlorite $>$ muscovite $>$ plagioclase $>$ calcite $>$ hematite. The neutralization of the dominant alumino-silicate minerals, traces of carbonates as calcite, and the absence of sulfide minerals in the tailings resulted in medium alkaline $\mathrm{pH}$ leachates $(7.97-8.37)$ at all depths, EC $(364-156.5 \mu \mathrm{S} / \mathrm{cm})$, $\operatorname{TDS}(18.8 \mathrm{mg} / \mathrm{L})$, and the low concentrations of dissolved $\mathrm{Cu}(20.21-47.9 \mu \mathrm{g} / \mathrm{L}), \mathrm{Zn}(0.88-1.80 \mu \mathrm{g} / \mathrm{L})$, $\mathrm{Pb}(0.27-0.34 \mu \mathrm{g} / \mathrm{L})$ in the tailings profiles leachates, indicating that the transport load of potentially toxic chemical species from tailings to aqueous phase is very low. This implies that the solubility and mobility of potentially toxic chemical species is very low within the aqueous phase as corroborated by their relative percentage leach (Ni 0.081\%, Cu 0.006\%, and Zn 0.05\%). MINTEQA2 speciation calculation showed that many of the potentially toxic chemical species occur as free ions in the tailings leachates, indicating the absence of soluble complexes or ligands such as sulfides or organic matter which are known to be the main solubility and mobility control for $\mathrm{Co}, \mathrm{Ni}, \mathrm{Zn}$, and $\mathrm{Cd}$ in the tailings. However, the dissolved concentration of sulfates was high $\left(\mathrm{SO}_{4}{ }^{2-} 15.71-55.94 \mathrm{mg} / \mathrm{L}\right)$ in the tailings leachates, and increased with increasing tailings depth, and this could lead to high salt content in the adjacent surface and groundwater systems. The increase in sulfates content in the tailings leachates is attributed to the possible application of sulfuric acid to enhance ore separation during past copper mining activities in Musina. The water-soluble concentrations of base metals followed the order: $\mathrm{Al}>\mathrm{Fe}>\mathrm{Mn}>\mathrm{Ca}>\mathrm{K}>\mathrm{Na}$ within the tailings profiles, which was 
consistent with the relative abundance of alumino-silicate minerals. Al and Fe were the metal species with the highest water-soluble concentrations (129-175 $\mu \mathrm{g} / \mathrm{L}$ and 71.6-143.5 $\mu \mathrm{g} / \mathrm{L}$, respectively). This indicates the presence of soluble alumino-silicates and absence of sulfidic minerals in the tailings profiles. Mineralogical analysis identified hematite peak as the secondary mineral, although MINTEQA2 speciation calculation showed that the tailings leachates were below saturation regarding oxyhydroxides and were oversaturated with cuprite $\left(\mathrm{Cu}_{2} \mathrm{O}\right)$. The precipitation of secondary hematite and cuprite under medium alkaline $\mathrm{pH}$ condition plays an important known ability to trap and attenuate the mobility of potentially toxic chemical species $(\mathrm{Cu}, \mathrm{Zn}$, and $\mathrm{Pb})$ through adsorption on the surface area. Therefore, neutralization, dissolution, and precipitation of the dominant mineralogical constituents as a function of the tailings $\mathrm{pH}$ were identified to be the geochemical controls for the solubility and mobility of potentially toxic chemical species, and their potential transfer from tailings to the aqueous phase.

Acknowledgments: The authors express their respective gratitude to the Department of Ecology and Resource Management, and the Department of Mining and Environmental Geology at the University of Venda for their respective interest and access to logistic support. The authors will also want to acknowledge the support from the Environmental Remediation and Water Chemistry Group. Furthermore, we sincerely thank the National Research Foundation (NRF), Sasol Inzalo, ESKOM their financial support.

Author Contributions: Rendani Thobakgale and Segun Ajayi Akinyemi, conceived and designed the experiments; Rendani Thobakgale performed the experiments; Rendani Thobakgale and Wilson Mugera Gitari analyzed the data; Wilson Mugera Gitari contributed reagents/materials/analysis tools; Wilson Mugera Gitari wrote the paper.

Conflicts of Interest: The authors declare no conflict of interest.

\section{References}

1. Department of Mineral Resources (DMR). The National for the Management of Derelict and Ownerless Mines in South Africa; Department of Mineral Resources: Pretoria, South Africa, 2009.

2. Fosso-Kankeu, E. $\mathrm{Ni}^{2+}$ Extraction from Low Grade Leachate of Tailings Dumps Material Using Cloned Indigenous Bacterial Species; University of Johannesburg: Johannesburg, South Africa, 2011.

3. Godfrey, L.; Oelofse, S.; Phiri, A.; Nahman, A.; Hall, J. Mineral Waste: The Required Governance Environment to Enable Reuse; Final Report, CSIR/NRE/ PW/IR/2007/0080/C; Council of Scientific and Industrial Research: New Delhi, India, 2007.

4. Thobakgale, R. Evaluation of the Geochemical and Mineralogical Transformation at an Old Copper Mine Tailings Dump, Limpopo Province, South Africa. Master's Thesis, University of Venda, Thohoyandou, South Africa, 2017.

5. AngloGold Ashanti. Stakeholder Involvement in the Closure Planning Process at Ergo. In Report to Society for 2004; AngloGold Ashanti: Johannesburg, South Africa, 2004; pp. E45-E48. Available online: https: / / thevault. exchange/?get_group_doc=143/1502780448-Reporttosociety2004.pdf (accessed on 7 February 2018).

6. Lottermoser, B.G. Mine Wastes: Characterization, Treatment and Environmental Impacts, 3rd ed.; Springer: Berlin, Germany, 2010; pp. 204-240.

7. Romero, F.M.; Armienta, M.A. Gonzales-Hernandez, G. Solid-phase control on the mobility of potentially toxic elements in an abandoned lead/zinc tailings impoundment, Taxco, Mexico. Appl. Geochem. 2007, 22, 109-127. [CrossRef]

8. Arenas-Lago, D.; Andrade, M.L.; Lago-Vila, M.; Rodríguez-Seijo, A.; Vega, F.A. Sequential extraction of heavy metals in soils from a copper mine: Distribution in geochemical fractions. Geoderma 2014, 10, 108-118. [CrossRef]

9. Hiller, E.; Petrák, M.; Tóth, R.; Voleková, B.L.; Jurkovic, L.; Kučerová, G.; Radková, A.; Šottník, P.; Vozár, J. Geochemical and mineralogical characterization of neutral, low-sulfide/high-carbonate tailings impoundments, Markušovce, eastern Slovakia. Environ. Sci. Pollut. Res. 2013, 20, 7627-7642. [CrossRef] [PubMed]

10. Rice, K.C.; Herman, J.S. Acidification of Earth: An assessment across mechanisms and scales. Appl. Geochem. 2012, 27, 1-14. [CrossRef]

11. Sracek, O.; Mihaljevic, M.B.; Kr`ibek, B.; Majer, V.; Veselovsky, F. Geochemistry and mineralogy of Cu and Co in mine tailings at the Copper belt, Zambia. J. Afr. Earth Sci. 2010, 57, 14-30. [CrossRef] 
12. McGregor, R.G.; Blowes, D.W. The physical, chemical and mineralogical Properties of three cemented layers within sulfide-bearing mine tailings. J. Geochem. Explor. Can. 2002, 76, 195-207. [CrossRef]

13. Ashton, P.; Love, D.; Mahachi, H.; Dirks, P. An Overview of the Impact of Mining and Mineral Processing Operations on Water Resources and Water Quality in the Zambezi, Limpopo and Olifants Catchments in Southern Africa; Project by CSIR Environmentek and Geology Department, University of Zimbabwe, Harare, Zimbabwe; Report No. ENV-P-C 2001-042; Mining, Minerals and Sustainable Development: Pretoria, South Africa, 2001.

14. Naicker, K.; Cukrowska, E.; McCarthy, T.S. Acid mine drainage arising from gold mining activity in Johannesburg, South Africa. Environ. Pollut. 2003, 122, 29-40. [CrossRef]

15. Bortnikova, S.; Bessonova, E.; Gaskova, O. Geochemistry of arsenic and metals in stored tailings of a Co-Ni arsenide-ore. Khovu-Aksy area, Russia. Appl. Geochem. 2012, 27, 2238-2250. [CrossRef]

16. Conesa, H.M.; Robinson, B.H.; Schulin, R.; Nowack, B. Metal extractability in acidic and neutral mine tailings from the Cartagena-La Unión mining district (SE Spain). Appl. Geochem. 2008, 23, 1232-1240. [CrossRef]

17. Gitari, M.W.; Akinyemi, S.A.; Thobakgale, R.; Ngoejana, P.C.; Ramugondo, L.; Matidza, M.; Mhlongo, S.E.; Dacosta, F.A.; Nemapate, N. Physicochemical and Mineralogical Characterization of Musina Mine Copper and New Union Gold Mine Tailings: Implications for Fabrication of Beneficial Geopolymeric Construction Materials. J. Afr. Earth Sci. 2018, 137, 218-228. [CrossRef]

18. Matshusa, K.; Makgae, M. Overview of Abandoned Mines in the Limpopo Province, South Africa: Rehabilitation Challenges. J. Environ. Sci. Eng. 2014, 15, 156-161.

19. Singo, N.K. An Assessment of Heavy Metal Pollution near an Old Copper Mine Tailings Dump in Musina, South Africa. Master's Thesis, University of South Africa, Johannesburg, South Africa, 2013.

20. Beale, C.O. Copper in South Africa-Part II. J. S. Afr. Inst. Min. Metall. 1985, 85, 109-124.

21. Cairncross, B.; Dixon, R. Minerals of South Africa; Geological Society of South Africa: Johannesburg, South Africa, 1995; ISBN 0-620-19324-7.

22. Brandl, G. The Geology of the Musina Area; Government Printer: Pretoria, South Africa, 1981.

23. ASTM D2216. Standard Test Methods for Laboratory Determination of Water (Moisture) Content of Soil and Rock by Mass; ASTM D2216-98; ASTM International: West Conshohocken, PA, USA, 1998.

24. The European Committee for Standardization. Characterization of Waste. Leaching. Compliance Test for Leaching of Granular Waste Materials and Sludge. One Stage Batch Test at a Liquid to Solid Ratio of $10 \mathrm{~L} / \mathrm{kg}$ for Materials with Particle Size below $4 \mathrm{~mm}$ (without or with Size Reduction); BS EN 12457-2:2002; The European Committee for Standardization (CEN): Brussels, Belgium, 2002.

25. World Health Organization (WHO). Guidelines for Drinking Water Quality, 4th ed.; World Health Organization (WHO): Geneva, Switzerland, 2011.

26. Gilbert, S.E.; Cooke, D.R.; Hollings, P. The effect of hardpan layers on the water chemistry from the leaching pyrrhotite-rich tailings material. Environ. Geol. 2003, 44, 687-697. [CrossRef]

27. Lottermoser, B.G.; Ashley, P.M. Mobility and retention of trace elements in hardpan-cemented cassiterite tailings, North Queensland, Australia. Environ. Geol. 2006, 50, 835-846. [CrossRef] 
28. Government Gazette of South Africa. South African Soil Quality Guidelines for All Land Uses; Report No. 35160 (561); Government Gazette: Pretoria, South Africa, 2012.

29. Dold, B. Basic concepts of environmental geochemistry of sulfide mine-waste. In Mineralogia, Geoquimica y Geomicrobiologia para el Manejo Ambiental de Desechos Mineros, Proceedings of the XXIV Curso Latinoamericano de Metalogenia UNESCO-SEG, Lima, Peru, 22 August-2 September 2005; Society of Economic Geologists (SEG): Littleton, CO, USA, 2005. 